Genetical Research Vol. 27, No. 1

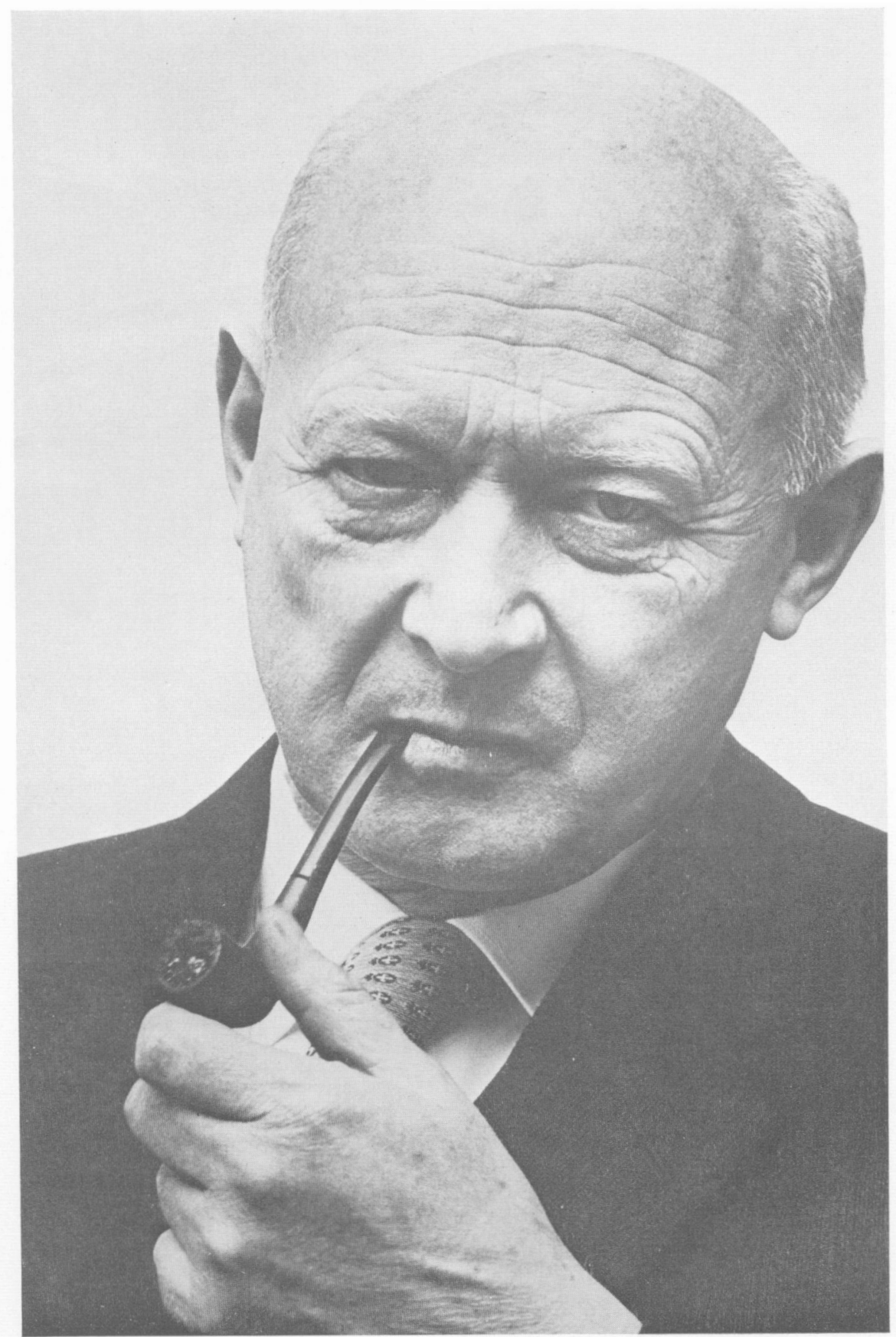

C. H. WADDLNGTON 


\section{Professor C. H. Waddington}

Professor C. H. Waddington, chairman of the editorial board of GENETICAL RESEARCH since its foundation in 1960, in which he played a major part, died suddenly on 27 September 1975. From an initial degree in geology, his first moves towards biology came from a study of ammonites. His research career started at the Strangeways Laboratory and he was one of a stimulating group of younger biologists in Cambridge in the 1930s which included, amongst others, Bernal, Pirie and Needham. Waddington's own earlier work in collaboration with Needham was in the exciting field of developmental induction and of the organiser, an approach which in the end proved not very fruitful with discoveries that cells could be triggered into development by a variety of stimuli. During the war, Waddington joined the Operational Research Section of Coastal Command, RAF, becoming its head in 1944. The remainder of his career was spent in Edinburgh as Buchanan Professor of Animal Genetics, holding at the same time an appointment first as deputy head of the Animal Breeding and Genetics Research Organisation of the Agricultural Research Council and then as Director of the ARC's Unit of Animal Genetics. During this period in Edinburgh, he rapidly built up a very large and flourishing Genetics Department, with financial support gleaned from many sources.

Waddington's main research interests in genetics were in the evolutionary aspects of embryology and development, to which he contributed many important new ideas. These are particularly exemplified by his studies on genetic assimilation, which went some way to resolving the conflict between Lamarckism and Darwinism by showing experimentally that 'acquired' characters could become 'inherited' by perfectly orthodox Darwinian selection, continued over a number of generations.

Waddington was an immensely productive writer, and published nearly 500 research papers and articles, as well as sixteen books. His book 'An Introduction to Modern Genetics' (1939) was for long the best textbook on genetics, and can still be read with profit. His early appreciation of the need to apply genetical ideas to the study of development found expression in four books which have had a lasting influence on biological thought: 'Organisers and Genes' (1940), 'The Epigenetics of Birds' (1952), 'Principles of Embryology' (1956) and 'The Strategy of the Genes' (1957). His ideas on evolution were recently summarised in 'The Evolution of an Evolutionist'.

His interests, however, were far wider than biology, and he wrote with authority and originality about the relation of science and society ('The Scientific Attitude', 1941; 'Biology for the Modern World', 1962), about ethics ('The Ethical Animal', 1967; 'Biology, Purpose and Ethics', 1971), and about art ('Behind Appearance', 1970). He was one of the three practising scientists who served on the Trend committee on the Organisation of Civil Science, which had such far-reaching effects on 
the structure of government-funded research in this country. He participated in several Pugwash Conferences and was a founder member of the Club of Rome, and in his last years he founded the School of the Man-Made Future in Edinburgh University. He was President of the International Union of Biological Sciences and was the driving force behind many of its activities, and he was the main originator and Vice-President of the International Biological Programme. 